\title{
Epiphrenic Diverticulum in an Infant with Congenital Esophageal Stenosis Associated with Esophageal Atresia
}

\author{
Özofagus Atrezisi ile İlişkili Doğumsal Özofagus Darlığı Olan Bir \\ Infantta Epifirenik Divertikül
}

\section{Cigdem UlUKAYA DURAKBASA $\odot$, Gursu KIYAN $\odot$, Sinem AYDONER $\odot$, Ahmet PIRIM $\odot$, Hatice SENELDIR $\odot$, Sercin OZKOK $\odot$, Ismail CAYMAZ $\odot$}

Ethics Committee Approval: Not Applicable.

Conflict of interest: The authors declare that they have no conflict of interest. Funding: None.

Informed Consent: Informed consent was taken.
Cite as: Durakbaşa CU, Kiyan G, Aydoner S, et al. Epiphrenic diverticulum in an infant with congenital esophageal stenosis associated with esophageal atresia. Medeni Med J. 2020;35:261-5.

\begin{abstract}
Congenital esophageal stenosis (CES) is a rare congenital disorder which may be isolated or associated with esophageal atresia (EA). It courses with esophageal outflow tract obstruction. Esophageal epiphrenic diverticulae are esophageal outpouchings above diaphragm which develop because of an underlying esophageal motor disorder. We present an infant who had CES associated with EA detected during the course of routine follow-up. She underwent several sessions of esophageal balloon dilatations for CES with some symptomatic improvement. However, an epiphrenic diverticulum (ED) developed during the course of treatment which was detected by further investigations. A surgical excision was performed with a successful outcome. An $E D$ developed secondary to CES has not been previously reported. We have highlighted the diagnostic modalities employed, treatment options, and clinical follow-up for these two rare conditions in children.
\end{abstract}

Keywords: Esophageal atresia, congenital esophageal stenosis, esophageal diverticula, epiphrenic diverticula, children

öz

Doğumsal özofagus darlı̆̆ı (DED) tek başına görülen veya özofagus atrezisine (ÖA) eşlik eden nadir bir doğumsal hastalıktır. DED özofagus boşalmasında tıkanıklık ile seyreder. Özofagusun epifirenik divertikülleri (ED) ise diyafram üstü seviyede oluşan özofagus çıkıntılarıdır. Altta yatan özofagus motor hastalıkları zemininde gelişirler. ÖA ameliyatı sonrasına rutin takip sırasında DED tanısı konan bir hasta sunulmuştur. Hastaya DED tedavisi amacıyla çeşitli kereler balon dilatasyon uygulanmış ve semptomlarında kısmi düzelme sağlanmıştır. Bu tedavi esnasında yapılan ileri tetkiklerle hastada ED gelişstiği tespit edilmiştir. Cerrahi rezeksiyon ile başarılı sonuç elde edilmiştir. DED nedeniyle gelişen ED daha önce bildirilmemiştir. Bu iki nadir duruma ilişkin uygulanan tanısal yöntemler, tedavi seçenekleri ve klinik izlem bulguları vurgulanmıştır.

Anahtar kelimeler: Ozofagus atrezisi, doğumsal özofagus darlığı, özofagus divertikülü, epifirenik divertikül, çocuk
Received: 8 May 2020

Accepted: 15 July 2020

Online First: 30 September 2020

Corresponding Author:

C.U. Durakbasa

ORCID: 0000-0002-6474-3407

Istanbul Medeniyet University

Faculty of Medicine, Goztepe

Training and Research Hospital,

Department of Pediatric Surgery, Istanbul, Turkey

cigdemulukaya@yahoo.com

S. Aydoner 3483-8974

A. Pirim

ORCID: 0000-0002-8427-2913

Istanbul Medeniyet University

Faculty of Medicine, Goztepe

Training and Research Hospital,

Department of Pediatric Surgery, Istanbul, Turkey

G. Kiyan

ORCID: 0000-0001-5461-353X

Marmara University Faculty of Medicine, Pendik Training and Research Hospital, Department of Pediatric Surgery, Istanbul, Turkey

H. Seneldir

ORCID: 0000-0002-1429-6776

Istanbul Medeniyet University

Faculty of Medicine, Goztepe

Training and Research Hospital,

Department of Pathology, Istanbul, Turkey

Sercin Ozkok

ORCID: 0000-0002-2176-5278 Ismail Caymaz

ORCID: 0000-0002-4426-9672

Istanbul Medeniyet University

Faculty of Medicine, Goztepe

Training and Research Hospital,

Department of Radiology, Istanbul, Turkey 


\section{INTRODUCTION}

Congenital esophageal stenosis (CES) is a rare disorder with an estimated incidence of 1 in 25.00050.000 live births ${ }^{1}$. It may be isolated or associated with esophageal atresia (EA). Esophageal diverticula are rare outpouchings of the esophagus. Epiphrenic diverticula (ED) develop in distal esophagus and comprise below $10 \%$ of all esophageal diverticula ${ }^{2}$. A coexistence of an ED with CES has not been previously reported.

\section{CASE REPORT}

A female baby born at 35 weeks of gestation with a birth weight of $2115 \mathrm{~g}$ had EA with distal tracheoesophageal fistula and no other associated anomalies. She underwent a primary esophageal repair via right thoracotomy on the $3^{\text {rd }}$ day of life. The postoperative course was complicated by an anastomotic leak which resolved spontaneously by conservative management. She was on full oral feeds when discharged on the $20^{\text {th }}$ postoperative day. Complementary feedings were introduced after the 6th month of age. She had increasing difficulty in swallowing solid foods over the ensuing months. An upper contrast study (UCS) showed a normal-caliber anastomotic site but a narrowing in the distal esophagus consistent with CES at one year of age (Figure 1a). An endoscopy (EG-450PE5, Fujinon) revealed a widely patent anastomosis at the $14^{\text {th }} \mathrm{cm}$ but a circular narrowing at the $20^{\text {th }} \mathrm{cm}$ which precluded entry into the stomach (Figure 2a-b). Endoscopic biopsies were taken and $13.5 \mathrm{~mm}$ balloon dilatation was applied (Figure 1b). Biopsy results showed normal esophageal mucosa. Results of a 24hour $\mathrm{pH}$ monitoring were within normal limits. Between the ages of 13-17 months, a total of 5 dilatations were undertaken reaching to a luminal diameter of $16.5 \mathrm{~mm}$ with some improvement in swallowing and occasional dysphagia. Each dilatation was event-free and devoid of any complications. A functional thoracic MRI, three months after the last dilatation, showed distal esophageal narrowing with dilatation in the upper $2 / 3$. The wall thickness of the distal half ranged between 2.5-2.8 mm with no detectable cartilaginous tissue. There was a left preaortic diverticular $17 \times 14$ $\mathrm{mm}$ cystic structure located $2 \mathrm{~cm}$ above gastroe-

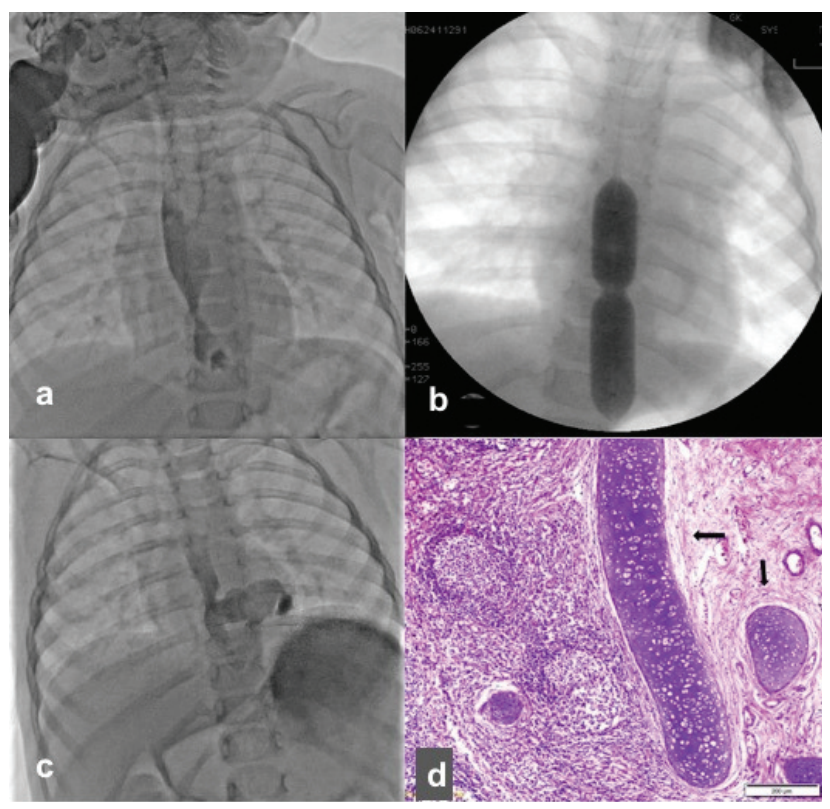

Figure 1. (a) Upper contrast study showing proximally dilated esophagus and a conical distal narrowing, (b) Initial balloon dilatation reaching to a size of $13.5 \mathrm{~mm}$, (c) Upper contrast study showing epiphrenic diverticulum above diaphragm, (d) Mature chondroid tissue (arrows) in the wall of the resected diverticulum (H\&EX100).

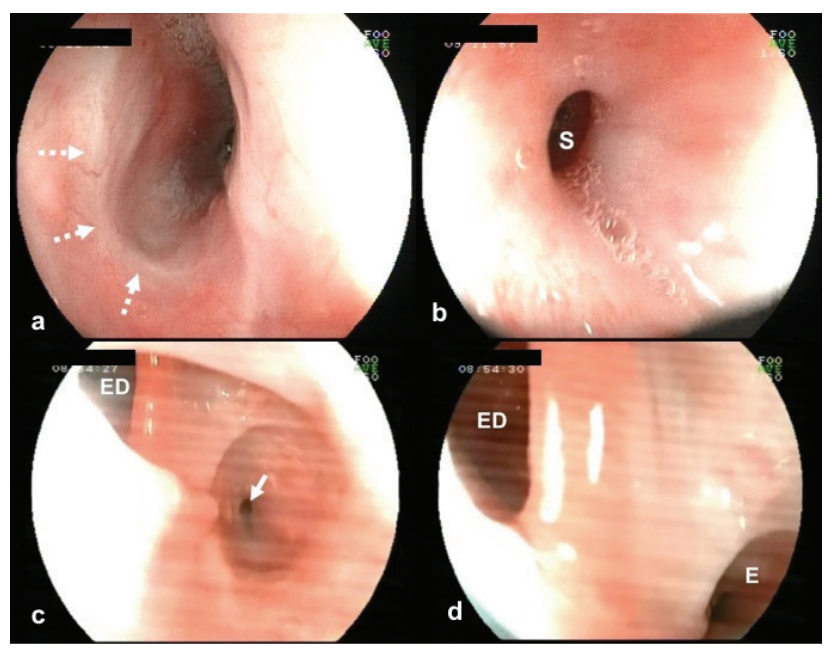

Figure 2. (a) Endoscopic view of proximal esophageal atresia repair site (arrows) which was widely patent, (b) Distal esophageal stenosis above gastroesophageal junction, (c,d) Endoscopic view of the epiphrenic diverticulum (ED) in relation to the esophagus (E) and the gastroesophageal junction (arrow). 
sophageal junction (Figure 3). A UCS confirmed the cystic structure was an ED (Figure 1c). An endoscopic assessment showed presence of a leftsided distal esophageal diverticulum which was non-existent in previous endoscopies performed with the endoscope passing though the GEJ into the stomach readily (Figure $2 c-d$ ). An operative intervention was decided. Through a left thoracotomy, the diverticulum was excised with the help of intraoperative endoscopy at the age of 21 months. The esophageal attachment side of the diverticulum had a stiff area and the remaining esophageal wall was of normal consistency. Thus, a semi-circumferential esophageal excision was included in diverticulectomy resection. Esophagus was primarily repaired. The postoperative course was uneventful. The histopathology revealed the excised diverticulum contained cartilaginous tissue on esophageal side (Figure 1d). A UCS obtained 3 months after the surgery was within normal limits. The patient was free of symptoms one year after the diverticulum surgery.

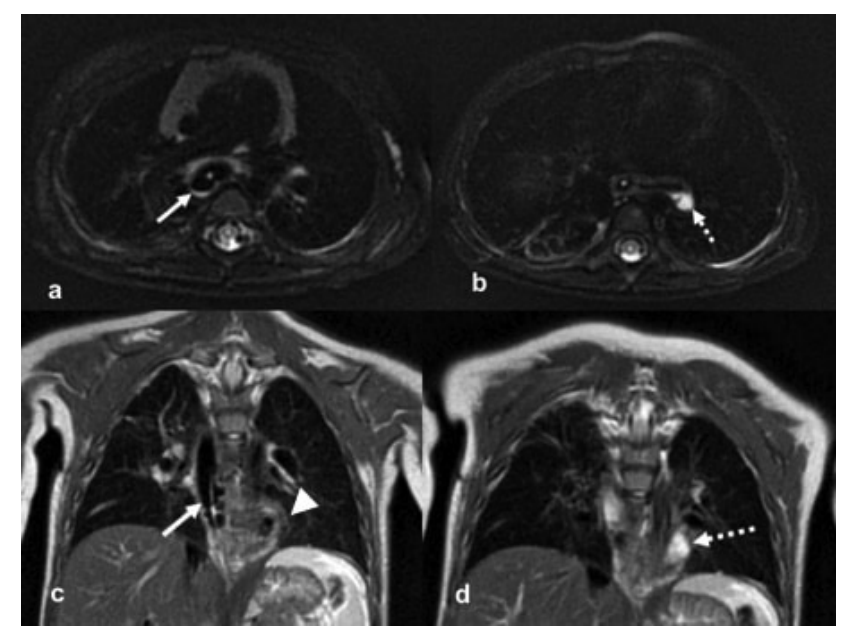

Figure 3: T2W1 magnetic resonance images (a) Axial view of dilated mid-esophagus (arrow) with an intraluminal feeding tube, (b) Cystic structure (broken arrow) with hyperintense air-fluid level and probable connection with esophageal lumen, (c) Coronal view of proximal portion of the cystic structure (arrow-head) lying on the same plane with the dilated mid-esophagus (arrow) which contains an intraluminal feeding tube (d) Cystic structure (broken arrow) with hyperintense air-fluid level.

\section{DISCUSSION}

EA is itself a rare disorder with a prevalence of 1:3.000-4.500. The presented patient had two additional esophageal conditions each of them is even rarer. Given the high incidence of gastroesophageal reflux (GER) in EA patients, a narrowing in the distal esophagus is most likely to be the result of a reflux-induced stricture in most cases. GER was excluded in the presented case by $24-$ hour $\mathrm{pH}$ monitoring results and histopathology findings obtained later on.

Distal esophageal narrowing observed after EA repair can rarely be due to CES which is associated with EA in 10-48\% of all reported cases ${ }^{1,3,4}$. Although the intrinsic luminal narrowing is congenital, most cases with CES become symptomatic after oral intake of semisolid or solid foods during infancy. The symptoms are progressive dysphagia, vomiting and/or food impaction. There are three histological variants: ectopic tracheobronchial remnants (TBR) in the wall, segmental fibromuscular hypertrophy (FMS) and a membranous diaphragm ${ }^{1}$. This distinction is important in terms of treatment options because cases with TBR are resistant to dilatations and therefore candidates for surgical resection and anastomosis. However, with available diagnostic methods namely, UCS, endoscopy, and crosssectional radiological imaging, a clear distinction is not possible in most cases ${ }^{3,4}$. Computed tomography was utilized in 17 CES patients out of 40 in one series and TBR could not be shown in any $^{3}$. Endoscopic ultrasonography can be of value to detect TBR, but it could almost never have been used in reported series because of its limited utilization in infants ${ }^{3,4}$. Therefore, as in our case, once CES is diagnosed in an infant, the first line of therapy is usually esophageal dilatation. Although it potentially bears the risk of perforation, balloon dilatation is a minimal invasive procedure in comparison to surgical resection. It is accepted as an effective treatment modality especially for FMS subtype. Infants who do not respond to serial 
dilatations are candidates for surgery. The number of dilatations before deciding surgical treatment should be individualized.

Although a prominent improvement in clinical findings was obtained by serial balloon dilatations, there was occasional dysphagia for solid foods in the presented case. Therefore, an MRI imaging was undertaken in order to detect whether TBRs were present in the esophageal wall. MRI did not show TBRs but to our surprise, an ED which was later confirmed by UCS and endoscopy was observed.

An ED is very rarely diagnosed in children. Esophageal diverticula are acquired pulsion diverticula located in the distal esophagus. They result from increased and/or uncoordinated intraluminal pressure with functional outflow obstruction which results in bulging out of the mucosa through a weak area in the muscle wall ${ }^{5,6}$. They are therefore usually associated with a concomitant esophageal motor disorder like hypertensive LES or achalasia. In the presented case, there was a "mechanical" esophageal outflow obstruction presumably with increased intraluminal pressure but intact peristaltic activity. Time needed to develop an ED in the setting of an esophageal motor disorder is obscure. In a series in which 27 patients with a mean age of 67 years and with a concomitant esophageal motor disorder, and an ED at presentation were included, the mean symptom duration of 3.6 years ranged from 3 months to 21 years ${ }^{6}$. So, we can conclude that, at least one patient in the series developed symptoms of esophageal motor disorder, and 3 months later the patient presented with concomitant motor disorder and an ED. However, the exact time interval needed to develop an ED on the basis of an esophageal motor disorder cannot be ascertained by available data.

An ED can only be managed by surgical interventions as thoracoscopy or open surgery. On the other hand, treating an ED without correcting the underlying disorder is regarded pointless ${ }^{2}$. Accordingly, in cases associated with achalasia, esophageal myotomy is added to the excisional surgery of diverticulum ${ }^{6}$. The presented patient had associated CSE, and we were not sure whether the patient had TBR type of the disorder which would necessitate the removal of congenital cartilaginous remnants within esophageal wall. We therefore opted for open surgery in order to be able to palpate the stenotic area of the esophagus, so that we could remove any area likely to contain TBR. In published reports most CSE cases with TBRs underwent esophageal resection of the involved segment followed by an end-to-end anastomosis ${ }^{4}$. Alternative techniques such as surgical myotomy, excision of a nodular structure on esophageal wall, resection of cartilaginous plate on esophageal wall, or local excision of stenotic area with fundal patch have also been described for treating esophageal stenosis with $\mathrm{TBR}^{1,7-9}$. Moreover, radical operations do not necessarily result in complete relief of the symptoms. In one series of 40 cases with CES, $44 \%$ of the patients still had symptoms after radical operations $^{3}$. In another series in which 24 patients underwent segmental esophageal resection and anastomosis, 66\% remained symptomatic after the operation ${ }^{4}$. A cartilaginous ring could not be palpated in our case but only a tiny area harder than the rest of the esophagus at the neck of the diverticulum could be felt. We therefore performed a partial resection of the esophageal wall including the stiffened area together with the diverticulum.

She was free of symptoms one year after the surgery and is currently being followed-up.

We presented this case not only because of coincidental presence of these rare esophageal disorders but also to emphasize the utilization of diagnostic armamentarium and treatment options available in the course of managing congenital esophageal disorders in infants. 


\section{References}

1. Nihoul-Fekete C, De Backer A, Lortat-Jacob S, Pellerin D. Congenital esophageal stenosis. A review of 20 cases. Pediatr Surg Int. 1987;2:86-92. [CrossRef]

2. Borrie J, Wilson RL. Oesophageal diverticula: principles of management and appraisal of classification. Thorax. 1980;35:759-67. [CrossRef]

3. Suzuhigashi M, Kaji T, Noguchi H, et al. Current characteristics and management of congenital esophageal stenosis: 40 consecutive cases from a multicenter study in the Kyushu area of Japan. Pediatr Surg Int. 2017;33:1035-40. [CrossRef]

4. Michaud L, Coutenier F, Podevin G, et al. Characteristics and management of congenital esophageal stenosis: findings from a multicenter study. Orphanet J Rare Dis. 2013;8:186. [CrossRef]

5. Tedesco P, Fisichella PM, Way LW, Patti MG. Cause and treatment of epiphrenic diverticula. Am J Surg. 2005;190(6):891-94. [CrossRef]

6. Brandeis AE, Singhal S, Lee TH, Mittal SK. Surgical management of epiphrenic diverticulum: A single-center experience and brief review of literature. Am J Surg. 2018;216(2):280-5. [CrossRef]

7. Terui K, Saito T, Mitsunaga T, Nakata M, Yoshida H. Endoscopic management for congenital esophageal stenosis: A systematic review. World J Gastrointest Endosc. 2015;7(3):183-91. [CrossRef]

8. Amae S, Nio M, Kamiyama T, et al. Clinical characteristics and management of congenital esophageal stenosis: a report on 14 cases. J Pediatr Surg. 2003;38:565-70. [CrossRef]

9. Yeung CK, Spitz L, Brereton RJ, Kiely EM, Leake J. Congenital esophageal stenosis due to tracheobronchial remnants: a rare but important association with esophageal atresia. J Pediatr Surg. 1992;27:852-5. [CrossRef] 